\title{
Pellon käyttö, maaperän ominaisuudet ja lieroyhteisöjen maantieteellinen vaihtelu
}

\author{
Mervi Nieminen ${ }^{1)}$, Visa Nuutinen ${ }^{1)}$, Juhani Terhivuo ${ }^{2)}$, Elise Ketoja ${ }^{1)}$, Taisto Sirén ${ }^{1)}$ \\ 1)Maa-ja elintarviketalouden tutkimuskeskus MTT,31600Jokioinen,etunimi.sukunimi@mtt.fi \\ 2) Luonnontieteellinen keskusmuseo, Eläinmuseo, PL 26, 00014 Helsingin yliopisto, \\ juhani.terhivuo@helsinki.fi
}

\section{Tiivistelmä}

Tämän Monimuotoisuuden tutkimusohjelmassa (MOSSE 2003-2006) toteutetun tutkimuksen tavoitteena oli muodostaa kokonaiskuva viljelymaan laadun kannalta tärkeiden lierojen esiintymisestä Suomen peltomaissa ja tunnistaa tärkeimmät runsauden vaihtelua aiheuttavat tekijät. Tarkoitusta varten kerättiin kenttäaineisto Etelä-Suomesta Lappiin ulottuneella näytteenotolla. Näytteet otettiin syksyjen 2004 ja 2005 aikana yhdeltätoista MTT:n tutkimusasemalta, asemien pelloille aiemmin perustetun maaperäseurannan näytepisteistä (yhteensä 53 peltopistettä). Pisteistä kerättyä maaperäaineistoa käytettiin yhdessä peltojen viljelyhistoriatietojen kanssa lieroyhteisöjen vaihtelun syiden selvittämisessä. Tulosten perusteella Suomen peltojen lierolajiston muodostaa yhdeksän lajia: neljä karikekerroksen lajia (onki-, metsä, rusko- ja punaliero), neljä pintamaan lajia (pelto-, multa-, harmaa- ja viherliero) ja yksi syvälle kaivautuva laji (kasteliero). Näistä yhdeksästä lajista yleisimmin esiintyivät pelto- kaste- ja onkiliero. Keskimäärin pellossa esiintyi kaksi ja pellon pientareella neljä lierolajia. Lierojen keskimääräinen yksilötiheys oli pellolla runsaat 100 yksilöä neliömetriä kohden kun taas pientareella tiheys oli yli kaksinkertainen siihen verrattuna. Lierojen runsaus vaihteli kokonaan tyhjistä peltopisteistä ( 3 pistettä) pisteisiin, joissa tiheys vastasi lähes tuhatta yksilöä ja tuorepaino runsasta 300 grammaa neliömetrillä. Kun pellot, jotka kaikki olivat kivennäismailla, jaettiin maalajin perusteella neljään luokkaan (savet, hiesut, hienot hiedat ja karkeat maat) erottuivat hiesut ja hienot hiedat muista korkean lierorunsauden maalajeina. Yleisin pellonkäyttö näytteenottohetkellä oli viljan viljely, säilörehunurmi tai laidun. Laitumilla lierojen kokonaistiheys oli selvästi muita pellonkäyttömuotoja korkeampi. Runsaat viljavuodet viljelykierrossa, ja vastaavasti taajaan tehty maanmuokkaus ja vähäiset nurmivuodet, olivat alentaneet lierojen kokonaismäärää hiesumailla mutta nostaneet hienoilla hietamailla. Kun maalajin, pellonkäytön ja viljavuosien määrän yhteys lierojen kokonaisrunsauteen otettiin huomioon, ei kokonaisrunsaudessa ollut enää merkittäviä eroja eri osissa maata sijaitsevien tutkimusasemien välillä. Tulosten perusteella pellon maaperän luontaiset ominaisuudet asettavat lierojen esiintymiselle puitteet, joissa viljely muovaa lieroyhteisön rakennetta. Tulosten avulla voidaan entistä paremmin ennakoida lieroyhteisön vastetta viljelytapojen muutoksiin erilaisissa olosuhteissa. Tulosten ensimmäinen sovelluskohde on ollut eri maalajeille määriteltyjen lierorunsauksien vertailuarvojen tarkentaminen maatalousneuvonnan käyttämässä viljelymaan laadun arvioinnissa.

Avainsanat: biodiversiteetti, monimuotoisuus, lierot, maaperäbiologia, agroekologia 


\section{Johdanto}

Maaperä tarjoaa useita kasvintuotannon sekä viljelymaan- ja ympäristönhoidon kannalta tärkeitä ekosysteemipalveluja. Maan orgaanisen aineksen hajotus, ravinteiden mineralisaatio sekä maan rakenteen muodostuminen ovat esimerkkejä palveluista, joissa maaperän eliöstöllä on merkittävä rooli. Maan makrofaunaan kuuluvat lierot lukeutuvat ns. ekosysteemi-insinööreihin sillä ne voivat vaikuttaa voimakkaasti maaperän eri prosesseihin ja siten säädellä muille eliöille tärkeiden resurssien saatavuutta. Suomessa lierolajisto koostuu kuudestatoista lajista. Lajit jaetaan kolmeen ekologiseen ryhmään, jotka eivät ole samanlaisia maaperävaikutuksiltaan ja ryhmät poikkeavat myös vasteiltaan viljelytoimenpiteisiin (Whalen \& Fox 2007).

Peltomaan lieroyhteisön monimuotoisuuteen vaikuttavat paikalliset olosuhteet sekä laajemmat alueelliset tekijät. Suomalaista tutkimustietoa on saatavilla paikallisten viljely- ja maanhoitotoimenpiteiden vaikutuksista peltojen lieroyhteisöjen rakenteeseen (esim. Haukka 1988, Kukkonen ym. 2004), mutta tieto alueellisten tekijöiden merkityksestä on hyvin puutteellista. Lierolajien levinneisyyksien pääpiirteet tunnetaan suomalaisissa luonnonvaraisissa biotoopeissa (Terhivuo 1988), mutta peltoympäristöjä koskeva alueellisen mittakaavan tietämys puuttuu. Myöskään monien maaperän perusominaisuuksien kuten maalajin ja lieroyhteisön lajikoostumuksen suhdetta ei juuri tunneta, vaikka on syytä olettaa maalajin vaikuttavan olennaisesti lierolajien esiintymiseen (Curry 2004).

Tämän tutkimuksen päätavoitteena oli muodostaa kokonaiskuva Suomen peltomaiden lieroyhteisöjen alueellisesta vaihtelusta ja tunnistaa vaihtelua aiheuttavat avaintekijät. Tavoitteena oli tietämys, jota voidaan käyttää ennustettaessa viljelytapojen muutosten vaikutuksia peltojen tilaan sekä kehitettäessä peltomaan laadun mittareita. Tutkimuksen lähtöoletuksena oli, että peltomaan luontaisten ominaisuuksien vaihtelu yhdessä pellon maantieteellisen sijainnin kanssa asettavat lierolajien esiintymiselle puitteet, joissa pellonkäyttö muovaa yhteisön rakennetta. Hankkeessa tutkittiin myös lierojen esiintymistä peltojen pientareilla tavoitteena selvittää pientareiden merkitystä pellon lierolajiston lähdealueina.

\section{Aineisto ja menetelmät}

Tutkimukseen valittiin mukaan 11 Maa- ja elintarviketalouden tutkimuskeskuksen (MTT) tutkimusasemaa. Asemat valittiin siten, että ne kattoivat mahdollisimman hyvin koko maan (Kuva 1). Peltolohkojen valinnassa asemien sisällä oli tärkeää, että lierojen kannalta olennaiseksi arvioitu maaperän ominaisuuksien vaihtelu tuli katettua (erityisesti maalajin, mutta myös maan orgaanisen hiilen määrän sekä happamuuden vaihtelu). Peltopisteet valittiin lohkoista, joiden maaperästä oli kerätty kattavasti perustietoja 1990luvulla aloitetussa maaperän raskasmetalliseurannassa (Urvas 1995). Kultakin asemalta otettiin mukaan 4-6 peltopistettä. Poikkeuksen teki Toholampi, josta mukaan tuli vain yksi pelto. Ensimmäisen näytteenottovuoden (2004) syksynä tutkittiin viisi asemaa (Mietoinen, Jokioinen, Laukaa, Ylistaro ja Maaninka), joissa maalajien vaihtelu oli savespitoisuudella mitattuna suurinta. Tavoitteena oli näin minimoida näytteenotto-ajankohdan vaihtelun häiritsevä vaikutus avainmuuttujaksi arvioidun maalajin merkityksen selvittämisessä. Toisen näytteenottovuoden (2005) syksynä kartoitettiin kuusi asemaa (Rovaniemi, Sotkamo, Ruukki, Toholampi, Juva ja Pälkäne).

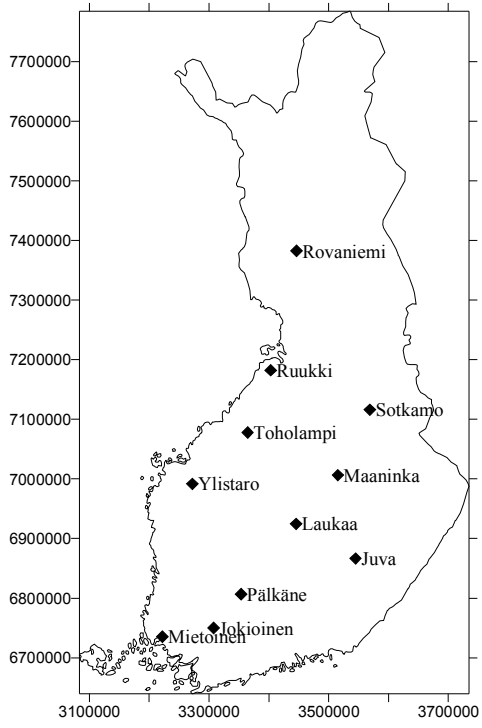

Kuva1. Tutkimuksen näytteenottopaikkakunnat.

Kustakin tutkimuksen 53 peltopisteestä otettiin kolme lieronäytettä, jotka sijaitsivat tasasivuisen $(5 \mathrm{~m})$ kolmion kärjissä maaperäseurantapisteen ympärillä. Piennarnäytepiste sijaitsi mahdollisimman lähellä peltopistettä, tyypillisesti pellon ja sitä ympäröivän ojan välisellä kapealla maakaistaleella. Piennarnäytteitä otettiin kolme kappaletta viiden metrin välein. Tutkittuja pientareita oli yhteensä 50 . 
Lieronäytteenotto tehtiin yhdistetyllä käsinlajittelu ja formaliininkaato -menetelmällä (ISO 23611-1:2006). Lierot määritettiin, aina kun mahdollista lajilleen ja yksilöt punnittiin. Maa- ja formaliininäytteistä löydettyjen lieroyksilöiden määrä ja massa laskettiin neliömetrikohtaisiksi arvoiksi ja summattiin yhteen lierojen kokonais- sekä lajikohtaisen runsauden määrittämiseksi.

Jokaisen pellolta otetun kolmen lieronäytteen vierestä otettiin maanäyte Oiva-kairalla $20 \mathrm{~cm}$ syvyyteen ja näytteet sekoitettiin kokoomanäytteeksi, josta määritettiin typen ja orgaanisen hiilen pitoisuus sekä pH. Maalajitietona on tässä käytetty aiemmin tehtyjä määrityksiä (Urvas 1995).

Näytepisteiden viljelyhistoriasta kerättiin tietoja näytteenottoa edeltävän kymmenen vuoden ajalta sellaisten toimenpiteiden osalta, joiden voitiin olettaa vaikuttavan lierojen runsauteen. Näitä olivat kyntökerrat, vilja-, nurmi- ja laidunvuosien määrä sekä orgaanisen lannoituksen käyttö. Näytteenottoa edeltävänä kasvukautena tutkituista pisteistä oli 23 viljalla, 17 nurmella, 6 laitumena, 5 viherkesantona ja 2 muussa käytössä. Muokkausmenetelmänä oli ollut pääasiassa syyskyntö. Orgaaninen lannoitus oli pelloilla ollut lähes poikkeuksetta lietelantaa.

Lierojen kokonaisrunsauden vaihteluun pellolla yhteydessä olevia tekijöitä tutkittiin käyttäen selittävinä muuttujina maaperän ominaisuuksia, pellon viljelyhistoriaa, sijaintia (asema) sekä näytteenottovuotta. Havaintoina analyyseissa käytettiin kustakin pelto- ja piennarpisteestä otetun kolmen näytteen keskiarvoja. Tilastollisessa analyysissä verrattiin lisäksi lierojen runsautta ja lajimäärää pellolla ja pientareella. Tässä yhteydessä tarkastellaan pääasiassa lierojen kokonaistiheyden vaihtelua ja yhteisön lajikoostumusta esitellään vain kuvailevasti.

Aineistojen mallinnuksissa käytettiin yleisiä lineaarisia sekamalleja. Mallien rakentamisessa otettiin huomioon aineiston hierarkkinen hankintatapa (kaksi vuotta, 5-6 asemaa/vuosi, 1-6 näytepistettä/asema). Lisäksi peltoa ja piennarta verrattaessa havaintojen väliset riippuvuudet otettiin huomioon mallien kovarianssirakenteiden valinnassa. Analyysit toteutettiin SAS/STAT-ohjelmiston MIXED-proseduurilla.

\section{Tulokset ja tulosten tarkastelu}

Lieroja esiintyi valtaosalla tutkituista peltoalueista, kokonaan ne puuttuivat vain kolmelta pellolta ja yhdeltä pientareelta. Piennaralueet huomioiden pelloilla esiintyi yhteensä yhdeksän lierolajia; epigeeiset pintakarikkeen lajit Lumbricus rubellus; ruskoliero, L. castaneus; metsäliero, Dendrobaena octaedra ja punaliero Dendrodrilus rubidus; endogeeiset pintamaan lajit peltoliero, Aporrectodea caliginosa; multaliero, A. rosea; harmaaliero, Octolasion tyrtaeum ja viherliero, Allolobophora chlorotica sekä syvälle kaivautuva laji kasteliero, L. terrestris.

Lierolajimäärä oli korkeimmillaan Etelä-Suomessa (Mietoinen: 8 lajia) vähentyen pohjoista kohti (Rovaniemi: 5 lajia), mikä vastaa suomalaisissa luonnonbiotoopeissa aiemmin havaittua kohti pohjoista vähenevää lajimäärää (Terhivuo 1988). Pohjoisimmalla asemalla (Rovaniemi) pellon puolelta löydettiin vain kaksi lajia, kun eteläisimmällä asemalla (Mietoinen) vastaava luku oli kuusi. Näitä alueellisia eroja ei voi kuitenkaan tulkita vain maantieteellisen sijainnin aiheuttamiksi, sillä asemat poikkesivat huomattavasti myös maalajien esiintymisen suhteen, karkeiden maiden painottuessa maan itä- ja pohjoisosiin, savien lounaiseen ja läntiseen Suomeen (ks. Urvas 1995). Aikaisemmin julkaistuihin levinneisyystietoihin verrattuna tehtiin kolmen lajin (multa-, rusko- ja harmaaliero) kohdalla tähän mennessä pohjoisimmat havainnot lajien esiintymisestä Suomessa (vrt. Terhivuo 1988). Viherlieroja tavattiin vain Lounais-Suomesta, mikä vastaa lajin aiempaa levinneisyyskuvaa.

Pellon puolella peltoliero oli selvästi yleisin laji, kaste- ja onkilieron ollessa seuraavaksi yleisimmät (Kuva 2A). Pientareilla kolmen yleisimmän lajin järjestys oli sama, mutta piennaryhteisön lajien jakauma oli peltoja tasaisempi kastelieron ja pintakarikkeen lajien suuremman yleisyyden vuoksi (Kuva 2B). Ruskolieroja tavattiin vain pientareelta. 

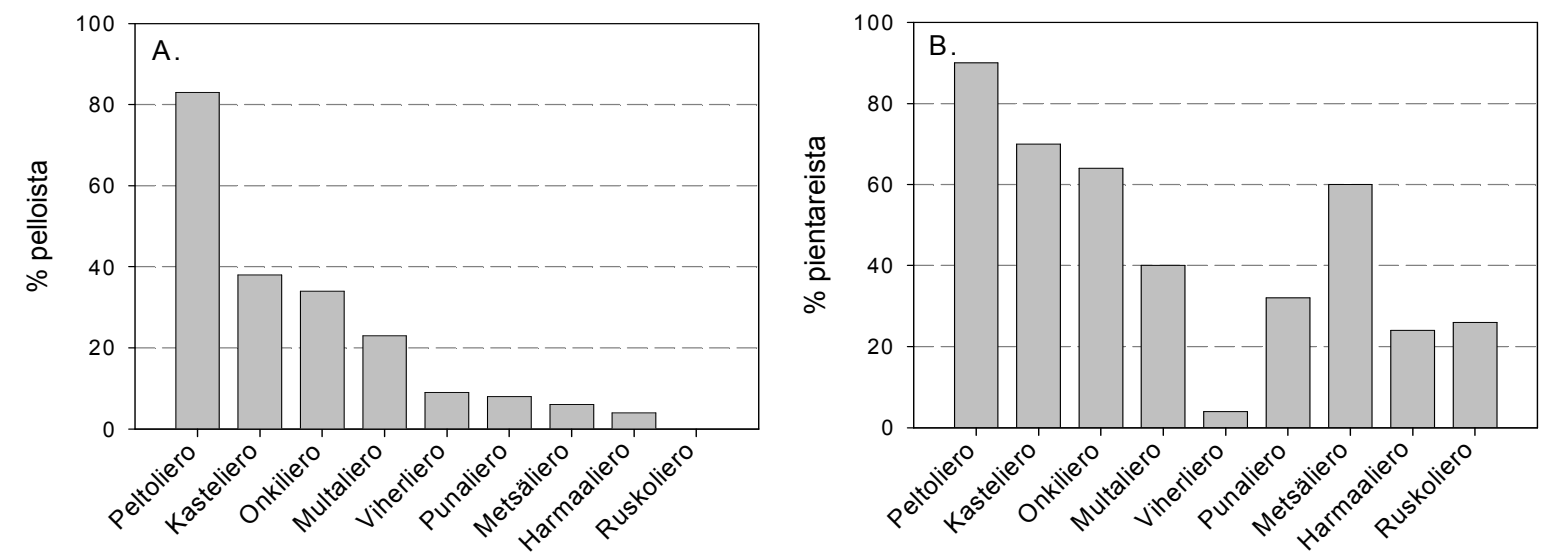

Kuva 2. Lierolajien esiintyminen tutkituissa A) pelto- ja B) piennarpisteissä.

Lieroyhteisön keskimääräinen lajimäärä oli pellolla kaksi ja pientareella neljä lajia (Kuva 3A). Lierojen keskimääräinen tiheys oli pellolla runsaat 100 yksilöä neliömetrillä kun pientareella tiheys oli siihen verrattuna 2.5-kertainen (Kuva 3B).
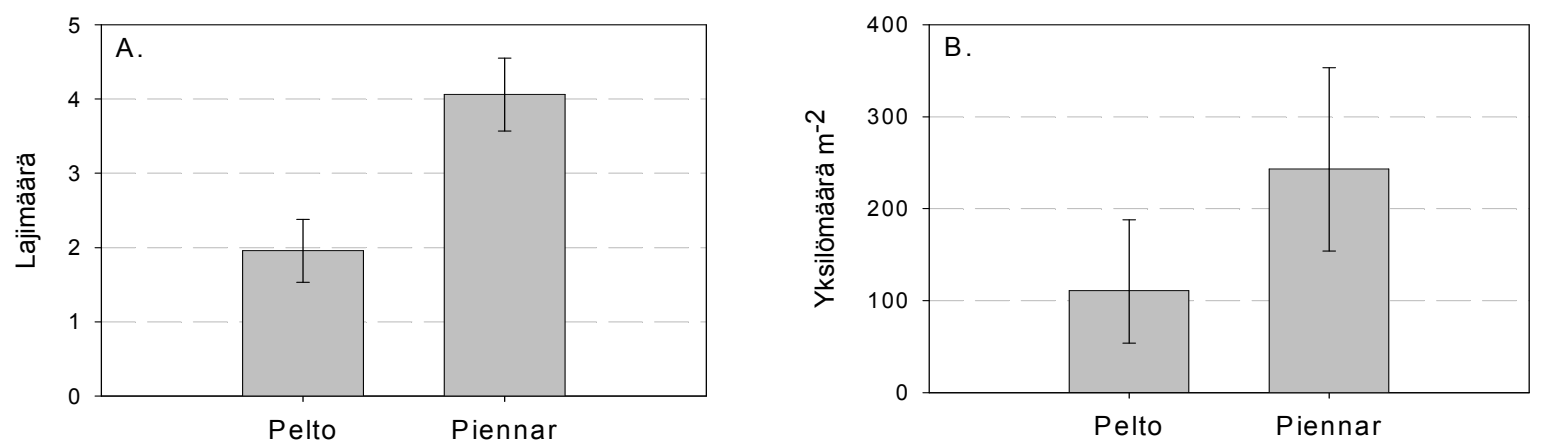

Kuva 3. Lieroyhteisöjen keskimääräinen lajimäärä (A) sekä lierojen keskimääräinen yksilötiheys (B) pellolla ja pientareella. Janat osoittavat keskiarvon 95\%:n luottamusvälin.

Lieroyhteisö koostui suurimmaksi osaksi pintamaan lajeista sekä pellolla että pientareella, mutta pientareella ero pintamaan lajien ja kahden muun lajiryhmän osuuden välillä oli huomattavasti pienempi kuin pellolla (Kuva 4).

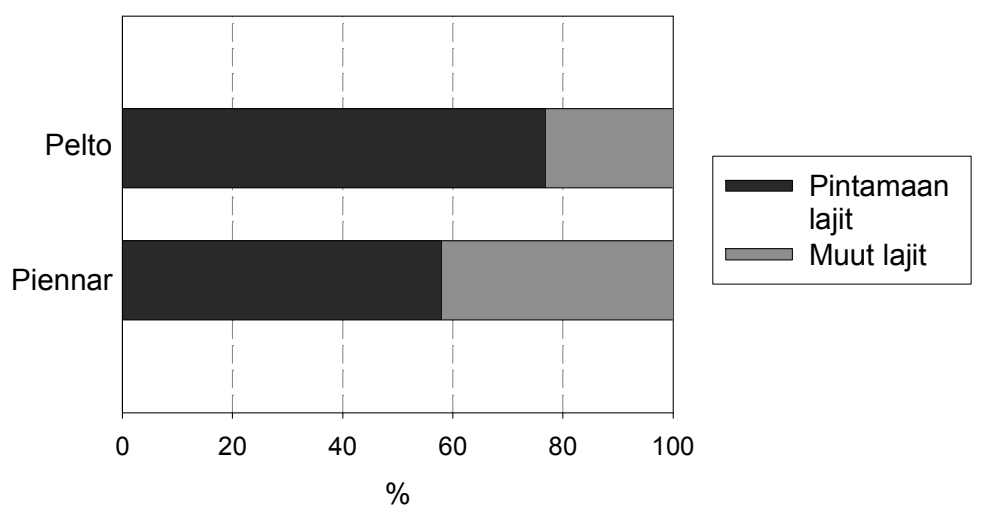

Kuva 4. Pintamaan lierolajien ja muiden lajien (kasteliero ja pintakarikkeen lajit) keskimääräinen osuus yksilömäärästä pellolla ja pientareella. 
Lierojen kokonaisrunsaus vaihteli pellolla suuresti yksilömäärän ollessa 0-1000 yksilöä ja tuorepainon 0-300 grammaa neliömetrillä. Parhaimmiksi lierojen kokonaisyksilömäärien (sekä kokonaismassan) vaihtelua pellolla selittäviksi muuttujiksi osoittautuivat pellon laidunkäyttö näytteenottovuonna $(\mathrm{p}<0.001)$ (laidun vs. ei-laidun), maalaji $(\mathrm{p}<0.0001)$ (neljä luokkaa; savet, hiesut, hienot hiedat ja karkeat maat), viljavuosien määrä näytteenottoa edeltävänä 10 vuotena $(\mathrm{p}=0.05)$ sekä maalajin ja viljavuosien määän yhdysvaikutus $(\mathrm{p}<0.005)$. Näihin muuttujiin perustuva malli selitti $63 \%$ lierojen kokonaisrunsauden vaihtelusta.

Näytteenottovuonna laidunkäytössä olleilla pelloilla lierojen yksilömäärä oli keskimäärin kuusinkertainen muuhun viljelyyn verrattuna (Kuva 5B). Eri maalajien yksilömäärien keskiarvot estimoitiin viidellä viljavuodella ei-laidunnetuilla mailla. Erot maalajien välillä ovat hyvin selkeitä. Lierojen keskimääräiset tiheydet ovat korkeimmillaan "keskikarkeilla" mailla: yksilömäärä on suurin hiesuilla ja seuraavaksi korkein hienoilla hiedoilla. Savilla ja karkeilla mailla keskimääräiset tiheydet ovat selvästi alempia (Kuva 5A).
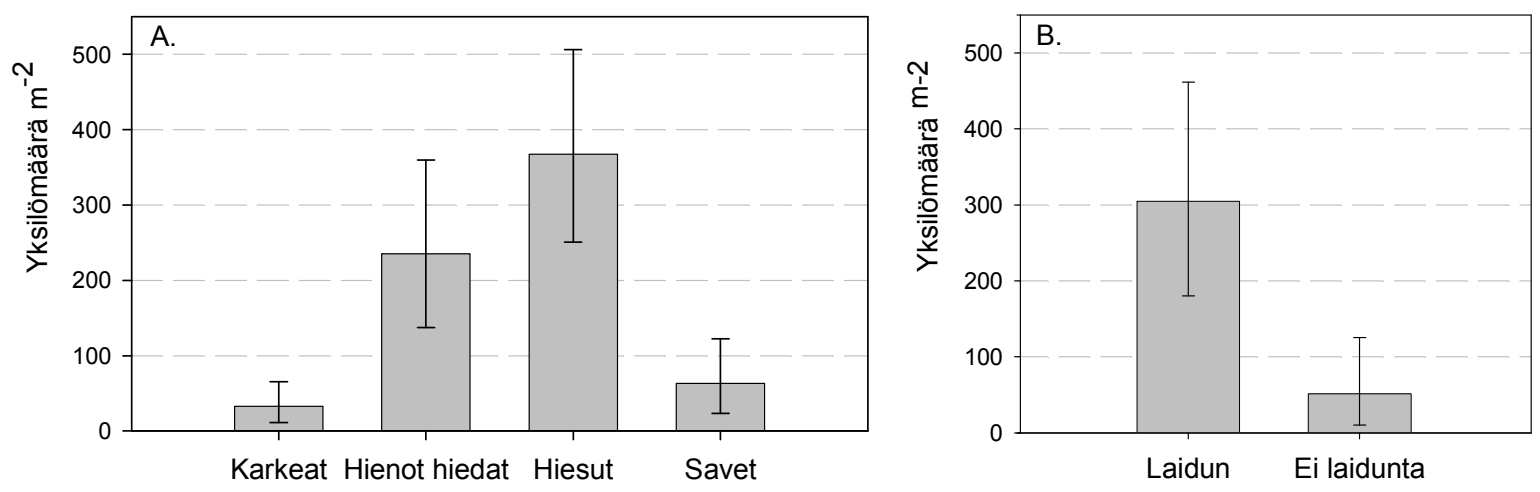

Kuva 5. Lierojen runsaus (A) eri maalajeilla ja (B) näytteenottovuonna laidunnetuilla ja laiduntamattomilla pelloilla. Kuvan B vertailuissa ovat mukana ne maalajit, joilla laitumia esiintyi. Janat osoittavat keskiarvon 95\%:n luottamusvälin.

Maalajien väliset erot lierotiheydessä olivat yhteydessä viljavuosien määrään. Hiesumailla runsaat viljavuodet (ja vastaavasti taajaan tehty muokkaus ja vähäiset nurmivuodet) olivat selkeästi vähentäneet lierojen määrää kun taas hienoilla hiedoilla useat viljavuodet näyttivät suosineen lieroja. Savimailla ja karkeilla mailla yhteys muuttujien välillä ei ollut yhtä selkeä. Muiden maaperän ominaisuuksien ja pellon viljelyhistoriaa kuvaavien muuttujien lisääminen malliin ei enää parantanut sitä. Maaperän ominaisuuksista maan happamuudella (vaihteluväli $\mathrm{pH}$ 4.6-7.0) ja orgaanisen aineksen pitoisuudella (orgC vaihteluväli 1.5-7.2\%) ei ollut yhteyttä lierorunsauden kanssa. Pellonkäyttöä kuvaavista muuttujista lannan käyttökerrat eivät vaikuttaneet lierojen runsauteen.

\section{Johtopäätökset}

Tulokset osoittavat lierojen esiintyvän yleisinä ja varsin runsaina Suomen viljellyissä kivennäismaissa. Lähtöoletuksia tukien maalaji osoittautui erityisen vahvaksi lierojen runsauteen vaikuttavaksi tekijäksi. Tutkimuksen tuloksia vastaavia havaintoja korkeammista lierotiheyksistä "keskikarkeilla" maalajeilla on tehty myös aiemmin (Guild 1948). Jossain määrin yllättävää oli, että peltojen maantieteellisellä sijainnilla ei ollut tilastollisesti erottuvaa yhteyttä lierojen kokonaisrunsauden kanssa kun muut vaihteluun vaikuttavat tekijät huomioitiin. Lieroyhteisöjen lajiryhmäkoostumus oli pelloilla hyvin samankaltainen kuin monissa aiemmissa paikallisissa tutkimuksissa, maanmuokkausta parhaiten sietävien pintamaan lajien vallitessa yhteisössä.

Pellonkäyttömuodoista laidunnus on todettu aiemminkin edulliseksi tekijäksi lierokantojen kasvulle (esim. Fraser ym. 1996). Lierot hyötyvät maan muokkaamattomuudesta, ravintoa tarjoavista laiduneläinten ulosteista sekä laitumien kasvilajikoostumuksesta (Whalen \& Fox 2007). Muokkauskerrat ja viljavuosien määä näytteenottoa edeltäneen 10 vuoden aikana olivat vahvasti kytköksissä toisiinsa. Hiesumailla todettu runsaiden viljavuosien määrän - ja usein toistuvan kynnön - 
lierokantaa alentava vaikutus vastasi monia aiempia tuloksia maanmuokkauksen kielteisistä vaikutuksista lieroihin (Wardle 1995). Hienoilla hiedoilla yhteys viljavuosien määrän ja lierotiheyden välillä oli kuitenkin päinvastainen. Yksi selitys ilmiölle voi olla kynnön poikkeava vaikutus pintamaan ominaisuuksiin ja lierojen elinolosuhteisiin eri maalajeilla (Nuutinen 1992).

Kiinteän karjanlannan käytöllä tiedetään olevan lierokantoja kasvattava vaikutus (Edwards 1983). Tutkituilla pelloilla oli kuitenkin käytetty pääsääntöisesti lietelantaa, jolla ei ole yhtä selkeää myönteistä - jos ei kantoja alentavaakaan - vaikutusta. Se selittänee osaltaan, ettei tutkimuksessa voitu havaita yhteyttä karjanlannan käyttökertojen ja lierojen runsauden välillä. Maan happamuudella ei myöskään havaittu yhteyttä lierojen kokonaismäärän kanssa mahdollisesti peltojen keskimäärin hyvän pH-tilan vuoksi. Puuttuva yhteys orgaanisen aineksen pitoisuuden ja lierorunsauden välillä osoitti, ettei kyseisen pitoisuuden käyttö maaperän biologista tilaa kuvaavana sijaismuuttujana ole ongelmatonta.

Vaikka lierojen kokonaisrunsauden vaihtelua kyettiin mallinnuksella selittämään varsin hyvin, selittämättä jäi parhaallakin mallilla yli kolmasosa vaihtelusta. Voi perustellusti olettaa, että osa tästä vaihtelusta liittyi tutkimatta jääneisiin peltomaan fysikaalisiin ominaisuuksiin, kuten maan tiiviyteen sekä maan kuivatustilaan. Nämä toisiinsa kytkeytyneet muuttujat ovat ilmeisen tärkeitä lierokantojen kokoa sääteleviä tekijöitä (Nuutinen ym. 2006).

Peltoon verrattuna pientareet osoittautuivat suhteellisesti ottaen lajirikkaiksi, tiheän lierokannan ympäristöiksi. Häiriintymätön maaprofiili pientareella suosii pintakarikkeessa eläviä lierolajeja sekä maan pinnalta ravintoa kerääviä kastelieroja. Nämä lajit lisääntyvät usein voimakkaasti maanmuokkauksen keventyessä sekä siirryttäessä suorakylvöön (Nuutinen 1992, Alakukku ym. 2004). Tuloksen perusteella lajit ovat usein "valmiina odottamassa" pientareella ja voivat levitä nopeastikin peltoon viljelymenetelmän muuttuessa niitä suosivaksi.

Hanke tuotti tavoitteensa mukaisesti tietoa, jota voidaan hyödyntää ennakoitaessa lieroyhteisön vastetta viljelymenetelmiin eri ympäristöissä sekä viljelymaan tilan seurannan kehitystyössä. Tulosten valossa voidaan esimerkiksi ymmärtää entistä paremmin, miksi lieroyhteisön vasteet samaan viljelymenetelmään voivat poiketa huomattavasti eri maalajeilla (Alakukku ym. 2004). Tutkimuksen tuloksia on jo hyödynnetty tarkennettaessa lierorunsauden vertailuarvoja maatalousneuvonnan käyttöön laaditussa peltomaan laatutestissä (Myllys ym. 2006).

\section{Kirjallisuus}

Alakukku, L., Turtola, E., Ventelä, A-M., Nuutinen, V., Aura, E. \& Uusitalo R. 2004. Suorakylvön soveltuvuus käytännön vesiensuojelutyöhön: esiselvitys. Pyhäjärvi-instituutin julkaisuja. Sarja A 28.92 s.

Curry, J.P. 2004. Factors affecting the abundance of earthworms in soils. Teoksessa: Edwards, C.A. (toim.). Earthworm Ecology. s. 91-113. Boca Raton: CRC Press. ISBN 0-8493-1819-X.

Edwards, C.A. 1983. Earthworm ecology in cultivated soils. Teoksessa: Satchell, J.E. (toim.). Earthworm Ecology. From Darwin to Vermiculture. s. 123-137. London: Chapman \& Hall.

Fraser, P.M., Williams, P.H. \& Haynes, R.J. 1996. Earthworm species, population size and biomass under different cropping systems across the Canterbury plains, New Zealand. Applied Soil Ecology 3: 49-57.

Guild, W.J.McL. 1948. Studies on the relationship between earthworms and soil fertility. III. The effect of soil type on the structure of earthworm populations. Annals of Applied Biology 35: 181-192.

Haukka, J. 1988. Effect of various cultivation methods on earthworm biomasses and communities on different soil types. Annales agriculturae Fenniae 27: 263-269.

ISO 23611-1:2006. Soil quality. Sampling of soil invertebrates. Part 1: Hand sorting and formalin extraction of earthworms.

Kukkonen, S., Palojärvi, A., Räkköläinen M. \& Vestberg, M. 2004. Peat amendment and production of different crop plants affect earthworm populations in field soil. Soil Biology \& Biochemistry 36: 415-423. 
Myllys, M., Alakukku L. \& Palojärvi, A. 2006. Peltomaan laadun mittaaminen tiloilla. Teoksessa: Räty, M. ym. (toim.) Miten maamme makaa - Suomen maaperä ja sen tila : IV Maaperätieteiden päivien laajennetut abstraktit. Pro terra 29: 40-41. http://www.maapera.fi/

Nuutinen, V. 1992. Earthworm community response to tillage and residue management on different soil types in southern Finland. Soil \& Tillage Research 23: 221-239.

Nuutinen, V., Ketoja, E., Nieminen, M. \& Sirén, T. 2006. Lieroistutus rakenteeltaan heikentyneen savimaan kunnostuksessa. Teoksessa: Alakukku, L. (toim.). Maaperän prosessit - pellon kunnon ja ympäristönhoidon perusta: MMM:n maaperätutkimusohjelman loppuraportti. Maa- ja elin-tarviketalous 82: 97-102. http://www.mtt.fi/met/pdf/met82.pdf Verkkojulkaisu päivitetty 9.8 .2006

Terhivuo, J. 1988. The Finnish Lumbricidae (Oligochaeta) fauna and its formation. Annales Zoologici Fennici 25: 229-247.

Urvas, L. 1995. Viljelymaan ravinne- ja raskasmetallipitoisuuksien seuranta. Maatalouden tutki-muskeskus. Tiedote $15 / 95.77 \mathrm{~s}$.

Wardle, D.A. 1995. Impact of disturbance on detritus food-webs in agroecosystems of contrasting tillage and weed management practices. Advances in Ecological Research 26: 105-185.

Whalen, J.K. \& Fox, C.A. 2007. Diversity of lumbricid earthworms in temperate agroecosystems. Teoksessa: Benckiser, G. \& Schnell, S. (toim.). Biodiversity in Agricultural Production Systems. s. 249-261. Boca Raton: CRC Taylor \& Francis. ISBN 1-57444-589-8. 